\title{
THE BUILDING OF THE EUROPEAN UNION'S FINANCIAL SYSTEM
}

\author{
János Müller
}

\begin{abstract}
In the period following the outbreak of the last financial crisis, a whole arsenal of regulatory tools and institutional infrastructure emerged to bolster the secure operation of the banking sector in the European Union. Considerable progress was made towards the establishment of the Economic and Monetary Union, the Banking Union and Capital Markets Union. A more nuanced, healthier regulatory system took shape, boosting the secure operation of the banking sector. Now we have reached several milestones: A decade has passed since the global financial crisis, the roots of the European Union have been strengthening for sixty years, the European Union is a quarter of a century old, the euro and the eurozone are twenty years old, and in 2019 we reached the end of two EU cycles that brought developments and lessons that could mark out the future of Europe.
\end{abstract}

JEL codes: $\mathrm{F}_{3}, \mathrm{G}_{2}$

Keywords: EU financial institutions; European Monetary Union; Capital Markets Union; Banking Union; Banking Authority; resolution; stability mechanism; monetary fund; capital requirement; bank supervision; supervisory authorities; single rulebook; FinTech; Fiscal Union.

\section{INTRODUCTION}

The events of recent times have put the European Union's viability to the test; but nevertheless, this has also been one of the longest crisis-free periods to date, creating the opportunity for calm economic growth and construction. Analysts dealing with this period bring up every variant from the envisioned collapse of the EU to its shining vision of the future, but less mention is made of the carefully considered construction work which, for the most part, has reached a professional maturity. This paper focuses on the institutional and regulatory environment that

1 János Müller, Chief Advisor, Hungarian Banking Association. Email: mullerj1@t-online.hu. 
emerged in connection with the operation of the European, and thus also the Hungarian banking sector.

In order to give an overview, we present how the architecture of the EU's financial and regulatory systems developed on the strong foundations of the EU, taking into consideration the lessons of the various challenges that arose. This overview needs to be placed in a historic perspective, because only in this way can we judge how strong, or deficient, is the superstructure that has been created to date. There is still plenty to do; certain parts of this metaphorical building need to be altered, but the structure itself is robust and strong. The leaders and decision-makers of the European Union are aware of the necessary directions for moving forward. Many of these steps are urgent, but the result is contingent on achieving a delicate balance, in terms of how decisions are influenced, between political interests, power dynamics and global and intra-EU economic constraints. These sensitive issues are the following: keeping up with the global competition and the increasingly fast pace of the digital world, confronting the situation that will emerge after any Brexit outcome, and managing the development-hindering problems of a two-speed Union and the eurosceptics.

We follow the past decade of evolution of the EU's financial institutional and regulatory system, and then outline the future vision that has taken shape with regard to 2019, which marks a change of cycle, and we also explore which of the important steps for moving forward have not been taken, and why not.

\subsection{The architecture of the financial system, and the first cycle (2009-2014)}

The second half of the 2010 brought considerable changes and forward-looking development for the European Union. This is especially true of 2019, which is a milestone year marking the transition to a new cycle. It was during this period that we were able to say, in the past tense, that most of the direct negative impacts of the 2008 global financial crisis for the banking sector, the recession and debt crisis, had been successfully overcome. There was a price to pay for this, in the form of the necessary overregulation of banking. At the same time, it was possible and indeed crucial to learn the lessons of the crisis. It was clear that when the crisis broke out neither regulation, nor supervision and crisis management were sufficiently effective; institutional and systemic answers had to be sought. A process got under way, underpinned by an in-depth analysis of the situation in post-crisis Europe and the intention to create the operating conditions for a banking sector that is capable of financing sustainable, competitive growth. The leaders of the EU agreed on the need to establish a system capable of giving advance warning of another crisis, and strongly mitigating the impacts of one that does occur. "The 
present will only fail to repeat the past if considerable forces gather to overcome it" wrote a Hungarian author. ${ }^{2}$ In the middle of the decade it seemed that considerable forces had indeed gathered for this purpose in the European Union.

The implementation of a regulatory structure, and the institutions facilitating its establishment and operation, got under way. The foundations of this architecture are not only to be found in the responses to the financial crisis. By 2008-2009, the EU had already evolved to the level at which it needed to decide on organisational and institutional reforms as an integral part of this.

What, then, were the foundations that it was possible to build on at the beginning of the two new EU cycles starting in 2009, and which created the opportunity to explore and seek the answers to existential questions?

In 2017 we celebrated the $60^{\text {th }}$ anniversary of the signing of the Treaty of Rome, based on which the European Economic Community was created with the participation of West Germany, France, Italy and the Benelux countries. Donald Tusk, President of the European Council, marked this occasion with the following words:

"Sixty years ago, statesmen from six countries decided that the only true freedom was the freedom to act together. ... The vulnerability of these frightened European countries gave them the humility, clarity and great wisdom to come together to sign the Treaty of Rome. That began a process that has since brought many more countries back to freedom and prosperity again, east and west. It has helped us to understand that when Europe is weak, her individual countries will be weak. If Europe is strong, her Member States are strong. Only by being united together, can we realise our own sovereignty - be truly free - in the wider world. That was true then, and it is true today. It will be true in another sixty years."

The next milestone came in 2018 , on the $25^{\text {th }}$ anniversary of the commencement of the Maastricht Treaty (the Treaty on the European Union), which facilitated the creation of the European Union. The European Union comprised three pillars: the European Communities, the European Economic Community, the European Coal and Steel Community and the European Atomic Energy Community (EAEC or Euratom). Besides this, the Maastricht Treaty also set out the requirements for the introduction of the euro. The purpose of the present article is also reflected in the sentiments expressed by the President of the European Commission on the anniversary:

2 UngVári, TAmás (2015): Csalódások kora [Age of Disappointments]. Budapest: Scolar, 2015, p. 519.

3 Donald Tusk (2017): Speech to Speakers of EU Parliaments in Rome, 17 March 2017. 
“... we cannot explain the European Union, the European project, simply by going back to history. That is important, but if we want to convince younger people that the European Union is a must today and in the years to come, we have to explain European history in perspective. What is Europe today and what will Europe be tomorrow and the day after tomorrow?"*

The year 2019 brought another red-letter day: the twentieth birthday of the EU's common currency the euro, launched on 1 January 1999. Achieving Economic and Monetary Union was an objective of the Maastricht Treaty, but the road to a common European currency took more than 20 years. Almost 30 years elapsed following the European Commission's first memorandum on this topic in 1969, a period encompassing the Werner report in 1970 and the signing of the Maastricht Treaty in 1992, before the euro was finally launched. In the first two decades of its existence the euro, becoming the second most important currency in the world, maintained its stability and role.

We invoke these these milestones on the road to today's European Union, the sixtieth, twenty-fifth and twentieth anniversaries, to give a sense of just how stable the foundations of the Union are. Now, building on these we can give an overview of what the 'landscape' of the European Union looked like at the start of the cycle that began in 2014 .

In this cycle, several decades of experience of the EU's operation, the impacts of the global financial and economic crisis that broke out in 2008, changes in global market positions and the emergence of geopolitical crises necessitated, and indeed forced, a rethinking of the EU's operating conditions and the introduction of measures and institutional reforms that had been identified long before, but were lent urgency by the aforementioned circumstances.

This situation gave the leaders of the European Union, the heads of the member states that proclaimed the Pan-European ideal, an opportunity to assess the situation that had emerged and to determine the policy tasks and priorities. They articulated two main conclusions: Firstly, the values-based operation of the EU needs to be strengthened, the EU values need to be more closely adhered to; and as a part of this, EU decisions need to be taken closer to EU citizens, the voters. Secondly, economic growth and job creation, improving EU competitiveness, must be treated as top policy priorities. This situational assessment and definition of policy priorities led to the acceptance and declaration of a principle whereby the European Union is a two-speed organisation, comprised of core countries and

4 Jean-Claude Juncker (2016): Speech by European Commission at the 25th Anniversary of the Maastricht Treaty: „EU and Me”. Maastricht, 9 December. 
the so-called periphery. The concept of strengthening the core countries gained political acceptance and was prioritised.

Based on all these developments it was clear that the EU's institutions needed to be reinforced, and the regulatory mechanism needed to be reviewed and made more effective. It was in this framework that the European Parliamentary Elections were held in 2014, leading to a renewal of the European Commission, the European Council and the European Parliament.

At the beginning of the 2014-2019 EU cycle that is now behind us the European leaders, assessing the impacts of the financial crisis, jointly resolved to move forward. There are many aspects of the efforts to mark out the new directions and future path that we could present here, but for the purposes of this analysis we must highlight two documents comprising forward-looking plans and guidelines.

The first is known as the Juncker Plan. The new President of the European Commission, Jean-Claude Juncker, presented his political programme after the European Parliamentary Elections, on 15 July 2014. "You are the first parliament to elect a President of the Commission", he said when introducing his programme. He announced a series of reforms intended to strengthen the social market economy, including a EUR 300 billion investment package with the aim of boosting growth, job creation and competitiveness.

He designated ten areas in which the EU should achieve tangible results during the five years of his mandate. Here we highlight those that are the most important from the perspective of our analysis: job creation; renewed faster growth in the economy and investments; a more integrated and fairer internal market with a strengthened industrial base; closer and fairer Economic and Monetary Union (EMU). An important stipulation related to the latter aspect was that the European Monetary Union (EMU) should continue to be reformed in the interest of maintaining the common currency, ensuring economic, fiscal and labour-market convergence for the eurozone countries. This wording, at the political level, raised the prospect of a two-speed European Union. The plan had one other point that deserves a mention in light of the present situation and future outlook: It called for a rational and balanced free-trade agreement with the United States, which must not endanger Europe's security, its healthcare, food safety, social and data protection systems, although the true integration of the transatlantic markets would clearly have been in the EU's best interests. As we know, this agreement was not signed after the change of US president, although given the present geopolitical tensions and the negative impacts of the trade war it would have been important not only for Europe, but for the USA as well. 
The other strategic document is the 'Five Presidents' Report', which includes an Action Plan and was published on 22 June 2015, taking effect on 1 July of the same year. 5

An important antecedent to the drafting of this report was the Euro Summit of October 2014, where a consensus was reached that "closer coordination of economic policies is essential to ensure the smooth functioning of the Economic and Monetary Union". The summit called for a continuation of the work "to develop concrete mechanisms for strong economic policy coordination, convergence and solidarity" and the elaboration of the "next steps on better economic governance in the euro area".

The thrust of the five presidents' proposal was that Economic and Monetary Union (EMU) has to be achieved in three stages between 2015 and 2025, with the stipulation that the focus should be on the institutions rather than on rules, in order to ensure that the EMU has a robust and transparent structure. Announcing the report, President Jean-Claude Juncker put it like this: "The euro is a currency shared by 19 EU Member States and more than 330 million citizens. It is something to be proud of. It is something that protects Europe. But it is also something that can work better. Our Economic and Monetary Union remains incomplete. ... Today we, five Presidents, are setting out our common vision. The world is watching us and they want to know where we are going. Today we lay out monetary integration and bring it to its ultimate destination."

The report defined three separate stages for achieving the future vision of the five presidents:

- Stage 1 - Deepening by doing (1 July 2015 to 30 June 2017): Boosting competitiveness and structural convergence, achieving responsible fiscal policies at national and euro area level, establishing the financial union.

- Stage 2 - Completing EMU: Further measures will be implemented to make the convergence process more binding, through a set of commonly agreement convergence benchmarks of a legal nature, as well as a euro area treasury.

- Stage 3 - Final stage (by 2025 at the latest): Once all the steps have been fully implemented, a genuine EMU will provide a stable and prosperous place for all citizens of EU Member States that use the common currency, and will become attractive for other EU Members States who are ready to join.

5 The five presidents: European Commission President Jean-Claude Juncker, European Council President Donald Tusk, Eurogroup President Jeroen Dijsselbloem, European Central Bank President Mario Draghi, and President of the European Parliament Martin Schulz. 
The report stated that closer coordination of economic policy is needed to ensure that the opportunities offered by the common currency and the area can be fully leveraged. Priority was given to four main areas of cooperation: Economic Union, Financial Union, Fiscal Union and Political Union.

An important task of the first stage was reviewing the European Semester. (The European Semester, launched in 2010, is a cyclical period for the coordination of fiscal and economic policies in the EU. The Semester is a part of the European Union's economic governance framework.) As a part of the review process, the National Competitiveness Boards and the European Fiscal Board had to be established.

The Five Presidents' Report dealt in-depth with strengthening the convergence process and boosting competitiveness, and with the issue of democratic accountability. Their proposal regarding the steps to be taken towards Financial Union and Fiscal Union are particularly important from the perspective of the banking sector. Regarding the former, they made it clear that the secure functioning of economic and financial union necessitates a single bank supervision mechanism, single bank resolution mechanism and single deposit insurance scheme. The objective of establishing a Single Supervisory Mechanism had already been achieved, and an agreement had been made regarding the Single Resolution Mechanism and the related Single Resolution Fund (which started operation on 1 January 2016). The next step, according to the report, would be the creation of the European Deposit Insurance Scheme.

To lay the foundations for the Fiscal Union, the European Fiscal Council was established with the role of performing a common macroeconomic stabilisation function. The decision was also taken to set up the European Fund for Strategic Investment.

These processes made it clear that the regulatory environment needed to be improved, and this was confirmed by the European Council's decision of May 2015. The Council concluded that better regulation is of key importance for stimulating economic growth and innovation, and for strengthening competitiveness and the single market. To this end, EU regulation needs to be straightforward and transparent, and should be applicable at the lowest possible cost. It was in this spirit that the Better Regulation for Better Results programme was launched.

\subsection{The construction continues. A new cycle, new challenges (2014-2019)}

In 2015, as a result of the developments outlined above, the conditions for achieving Capital Markets Union came into focus, the basic principle being that the best possible balance should be found between managing the crisis and supporting growth. 
On 30 September 2015 the European Commission unveiled the Action Plan for Capital Markets Union with the objective of creating a true single capital market extending to all 28 member states. ${ }^{6}$

Capital Markets Union is an important pillar of the Investment Plan; its purpose is to raise the undesirably low level of investments, and the first step in this is to determine the business objectives and to increase and diversify the sources of funding for long-term projects.

The four principles of the Capital Markets Union:

1) Creating more and better opportunities for investors

2) Linking funding to the real economy.

3) Creating a more resilient and robust financial system.

4) Strengthening financial integration and boosting competition.

Moving forwards in time, it should be mentioned that the European Council decided in July 2017 to initiate a Commission review of the Action Plan for Capital Markets Union. The Council reaffirmed its commitment to the Action Plan, which aims to establish comprehensive Capital Markets Union by the end of 2019: "The European economy is steadily improving. What we now need most of all is more investments. That's why the Capital Markets Union is a key element of the programme approved by the Commission. To ensure sustainable economic growth in the longer term, it is essential to broaden the range of sources available for financing, in particular for young and innovative companies."

An important step with regard to the European banking sector's operating environment was taken in June 2016, when the European Commission accepted the proposal of the Joint Committee of the EU and the EEA (European Economic Area) Joint Committee, which it proposed to the European Council in the interest of incorporating the rules of the European Supervisory Authorities and a series of related rules and directives into the legal system of the EEA.

This boosted the EU's economic power and competitiveness. The laws concerned are the following: Regulation on the European Supervisory Authorities (EBA, EIOPA and ESMA); European Systemic Risk Board Regulation; Alternative Investment Fund Managers Directive; Short Selling Regulation; European Markets Infrastructure Regulation (EMIR); Credit Rating Agency Regulation.

6 EC (2015): Capital Market Union: An Action Plan to boost business funding and investment financing. ECFIN E-news, Iss. 124, 1 October. 
The adoption of these laws and regulations created the conditions for strong and coordinated financial supervision across the European Economic Area.

Another milestone is the agreement made in the Committee of Permanent Representatives (COREPER) in June 2016 regarding Money Market Funds (MMF) reform, which was also supported by the Commission.

The proposal relating to the MMF regulatory frameworks was approved by the Commission in September 2013 to enable quantification of the impact that the new regulations would have on the financial system. These proposals took into account the October 2012 proposals of the Financial Stability Board (FSB). Acceptance of the FSB proposals represented a step forward in that the Funds became more resilient to redemption runs in a stressed market, while continuing to be safe tools for corporate financing in Europe.

Halfway through the EU cycle that began in 2014, the leaders of the EU decided it was time to assess the State of the Union and outline the possible directions for development.

In March 2017, "the President of the European Commission unveiled a white paper on the future of the European Union, which outlines five possible scenarios for the post-Brexit future. The first is about maintaining the status quo: Integration would become closer in certain areas, but the member states would retain the most important elements of their sovereignty. Under the second, the Union would gradually recentre on the single internal market. The third outlines the concept of a multi-speed Europe. Based on the fourth, member states would deepen their cooperation in certain policy areas while doing less elsewhere. The fifth scenario is a shift towards a more deeply integrated, federal Europe."?

Besides a reaffirmation of the Lisbon Treaty and the reform of several of its points, they also proposed creating the post of an EU Minister of Finance, with responsibility for articulating common EU economic and fiscal policy.

From our perspective, in terms of the possible directions for development of the banking sector, the proposals aimed at strengthening the euro area represented an important milestone. Under these, the economies of the euro area need to be brought closer together and made more resilient to external shocks. A convergence strategy is taking shape that would be based on a special, euro area budget funded by the member states, from which funds could be secured in a transparent manner.

7 1. See also: Haszon magazine, March 2017

2. EU-EP (2017): Az EU Parlament víziója, jövőképe Európa jövőjéről [Parliament sets out its vision for the future of Europe]. Plenary Session Press release - Future of Europe/European integration / Institutions, 16-02-2017). 
To achieve this, it was considered necessary to establish a special fiscal capacity, part of which is the European Stability Mechanism (ESM), as well as additional budgetary funds for the euro area, financed by member states as a part of the EU budget. Another proposal was to set up the European Monetary Fund, which would develop incrementally on the basis of the ESM, and would have the necessary lending and borrowing capacity. (It should be noted that a majority of the European Parliament voted in favour of this vision.)

As a part of this process, the 'Convergence Code' was drawn up, stipulating a fiveyear deadline for achieving compliance with the convergence criteria with respect to taxation, the labour market, productivity and social cohesion.

Here, we also briefly quote some Hungarian views on the visions of Europe outlined above. A few days before the aforementioned sitting of the European Parliament, Mihály Varga (then Minister for the National Economy, currently Minister for Finance) made the following comments to Bloomberg (as quoted by portfolio. hu on 27 February 2017):

"Two-speed Europe: He believes there's a risk that those who think in terms of a two-speed Europe will now start saying that those who are in the euro area are in the club, and those who aren't are left out.

This could bring the danger that the gap between developed and less developed member states will not decrease significantly in the era of a two-speed, post-Brexit Europe, which in turn could generate social tension and unrest," he warned. Mihály Varga repeated his previous statement to the effect that "It is not currently in Hungary's interests to adopt the euro. A new world is opening up, and in this new world there are challenges to our economic convergence."

The minister, therefore, confirmed that the emergence of a two-speed Europe is a genuine risk, primarily for those who are or remain outside the euro area; but Hungary does not intend to adopt the euro. In the short term, it does not aim to become a member of the euro area.

The next important step in the development and construction came when, following his comments of November 2016 on the European Commission's "Risk Reduction Package", the President of the European Banking Authority (EBA) notified the European Parliament of proposed amendments to the law on the banking and financial sector. In agreement with the European Commission, he proposed the approval of amendments to the Capital Requirements Regulation (CRR), the Capital Requirements Directive (CRD), the Bank Recovery and Resolution Directive (BRRD) and the Single Resolution Mechanism Regulation (SRMR).

These proposals were aimed at applying, and integrating into the EU regulatory system, the key elements of international standards formulated by the Basel Committee on Banking Supervision (BCBS) and the Financial Stability Board (FSB). 
One consequence of the proposals is the need for the EU's regulatory frameworks to be harmonised with the international standards. Other requirements were the proportionate use of common rules, and the balancing of differentiated compliance processes in a way that reflects the complexity and risks of banking operations.

The aim, therefore, was to achieve better proportionality, to simplify application of the Single Rulebook, and to reduce unnecessary regulatory burdens, without compromising on the prudential objectives.

The EBA strongly recommended the use of the Bank Recovery and Resolution Directive (BRRD) in the event of crisis management. This is different from rescuing banks with taxpayers' money (bail-out), and gives preference to the management of losses through international private investors (bail-in). There is only one possible exception to this rule, namely precautionary capitalisation from public funds under special circumstances.

To support this principle, the EBA proposed the establishment of a European Asset Management Company (AMC) or the preparation of scenarios for national asset managers to make market unrest, bankruptcies, rapid recovery and the problem of non-performing loans manageable. The Commission accepted the EBA's proposals almost without exception.

In the second half of the cycle beginning in 2014, it was clear that the EU's advisory and decision-making institutions were focusing on how the money-market institutions that had been established and put into operation to date, the banking regulatory and supervisory system, could and should be further developed and refined. They examined in detail what had been achieved and was working well, what modifications were necessary, and what elements were still missing. With regard to the latter, they also assessed whether there was enough political will and agreement for certain steps (such as the Fiscal Union). In the course of its development, the EU has also faced new challenges, to which it has had to react. One such issue, for example, was the requirement to establish a Digital Single Market. In what follows, we give an overview of these processes.

\subsection{Second half of the cycle (2017-2019)}

On 11 July 2017, the European Council decided on a Commission review of the Action Plan for Capital Markets Union.

The Council reaffirmed its commitment to the Action Plan, which set out to achieve a comprehensive Capital Markets Union by the end of 2019. The Council highlighted that implementation of the Action Plan was progressing well, with almost two thirds of the measures already in place. However, since its launch in 
September 2015 several new challenges had emerged that made it necessary to strengthen the Action Plan. As a part of this, it was necessary to strengthen the capital markets, making European companies and infrastructure projects more attractive to domestic and foreign investors. It was also necessary to improve access to funds, above all for European SMEs and startups, especially in the innovative sectors.

In December 2017, the European Commission proposed a Road Map and specific measures aimed at achieving a further strengthening of the Economic and Monetary Union and fulfilment of the objectives and undertakings determined in the Juncker Plan and the Five Presidents' Report. The European Commission described its schedule for deepening the Economic and Monetary Union, and within this the concrete actions to be taken in the next 18 months. The primary objective was for the European Economic and Monetary Union to become deeper, more effective and more democratically accountable by 2025 . The European Commission also accepted the proposal on establishment of the European Monetary Fund (EMF). The Monetary Fund builds on the tried and tested structure of the European Stability Mechanism (ESM) and is integrated with the EU's legal system.

It was clear at the beginning of 2018 that the banks' situation had improved; but boosting profitability and cleaning the banks' balance sheets continued to be a primary objective.

As regards profitability, the European banks were slow in adapting to the consequences of the crisis; slower than their American counterparts, for example. Return on equity generally improved at banks in the euro area, but for certain banks it was still very low. Nevertheless, in 2018 the general economic state of the EU offered good opportunities for the management of these tasks. The euro area was functioning well, the economy had grown every year for almost five years, whether you examined whole countries or individual sectors. Basel III had been completed by the Basel Committee, resulting in a more stable money market for banks, which also related to the regulatory conditions. Although the full application of Basel III was still to be achieved, its incorporation into the legal order of the EU could only take place after that. In 2018 the Single Supervisory Mechanism was in its fourth year of operation, and the period of construction was clearly over. The supervisory framework had become more stable and more predictable. To ensure the banks' more stable operation, it was important that the internal risk measurement models that they used resulted in appropriate risk weightings. It was at this point that the European Central Bank launched its Targeted Review of Internal Models (TRIM) programme. 
At the end of 2018, based on the experience accumulated so far, the requirements for further developing and deepening the Economic and Monetary Union were articulated in increasingly strong terms. There was no ignoring the fact that the adoption of the euro, the creation of the euro area, had clear advantages for the nineteen countries that used the euro. A currency zone with many common rules had been created, but the responsibility for economic and fiscal policy remained with the national governments.

A deepening of political and economic convergence is essential in order to achieve full Economic and Monetary Union. This was recognised long ago in the EU: If economic convergence is insufficient and there is no common fiscal policy, then closer political coordination is needed. To put it another way, political integration and economic convergence is required; the euro area must be strengthened and developed into a true economic union.

To this end, the previously proposed and commenced structural reforms must be continued and implemented. The European Commission recommended that the member states also support the reform efforts through the EU's budget, by selecting the reforms based on the impact that they have on the macroeconomic outlook. The funds used to support the reforms should be shared out on the basis of a quality assessment rather than a given country's entitlement to a 'slice of the cake'. Moreover, a disciplined feedback mechanism is needed, so that the funds are repayable if the agreed reforms are not carried out.

In addition to the structural reforms, it is essential to establish a stable fiscal policy. Common fiscal rules are capable of ensuring that member states do not take on excessive debt, because the low level of debt and greater buffers give the countries more budgetary elbow room for mitigating the impacts of economic recessions.

The establishment of a central fiscal capacity was stipulated as an essential tool, which would boost the euro area's resistance to severe recessions affecting the whole area, thus supporting monetary policy.

The 2008 crisis caught the European Union unawares, and the recession that occurred in 2012 contributed to the rapid decision that enabled EU leaders to agree, in the same year, on the establishment of the Banking Union. The first pillar of this was the Single Rulebook, followed by the EU-level bank supervision institution, the Single Supervisory Mechanism (SSM). In 2018, the time was ripe for the next step - creation of the third pillar of the Banking Union, which was the Single Resolution Mechanism. This helps the resolution of failing banks while minimising the broader impact on the economy and the financial system, while ensuring that any problems that arise are not primarily paid for by taxpayers. The most important element of the mechanism is the Single Resolution Board (SRB). 
Its task is to respond quickly and assertively if the operations of a systemically important or cross-border bank runs into financial difficulties. The Single Resolution Board was also created as a supranational decision-making authority of the Banking Union.

In June 2018 the European Summit approved, by mutual consent, the supplementation of the European Stability Mechanism (ESM) with the Common Backstop, which is only available as a last resort, and must be repaid by the banking sector if used. The Backstop is provided by the ESM as a line of credit available to the SRF as a last refuge. The Backstop does not burden public finances, because in the medium term the banking sector covers the cost of its use with ex-post contributions that assure tax neutrality.

In the foregoing we saw how the existing 'three pillars' of the Banking Union, the Single Supervisory Mechanism (SSM), the Single Resolution Mechanism (SRM), the European Deposit Insurance Scheme (EDIS) have been constantly reinforced and augmented to improve their operation.

At the end of 2017 it was proposed that, in order to further strengthen the Capital Markets Union another pillar was needed in the form of the European Asset Management Company (EAMC), which is capable of managing the problem of non-performing loans and lowering NPL rates, thereby supporting investments and growth in the euro area. ${ }^{8}$

The full completion of the Banking Union, in parallel with the progress made towards reducing and sharing risks, were intended to assist the cross-border integration of the financial sector; and as such this is one of the most important shortterm prerequisite for deeper European Economic and Monetary Union.

On 6 December 2018, which is celebrated as 'St. Nicholas Day' in many European countries, the Commission unveiled its 'Christmas stocking' or 'St Nicholas package' of Monetary Union reforms. This proposes the establishment of the European Monetary Fund (EMF) as an integral part of the EU's legal framework. The basis of the EMF is the European Stability Mechanism (ESM), and its purpose is to help member states and the banks during times of financial difficulty.

In addition to this, the Commission proposed the creation of an Investment Protection Scheme, which would have a macroeconomic stabilising effect in the event of an asymmetric shock. This also means that the Commission wants to continue funding state investments during times of crisis, if member states are limited in their ability to do so due to the fiscal regulations.

8 Helen Louri (2017): A fourth pillar for Europe's Banking Union? The case for a Pan-European Asset Management Company in the Eurozone. European Politics and Policy, London School of Economics, 6 December. 
The Investment Protection Scheme is a positive step for the mitigation of crisis impacts affecting the individual EU countries. Until now there has been no opportunity to counter the impacts of a crisis with investments. ${ }^{9}$

Another development related to the processes described above was that on $12 \mathrm{De}$ cember 2017 the European Council extended the term of the European Fund for Strategic Investment until 31 December 2020, budgeting for a further half a billion euros in investments.

Also released in December 2018 was the Commission's statement on the future of the euro area as a whole, according to which, based on the decisions of the European council and Euro Summit of December, the Commission will implement measures to strengthen the common currency's global role. ${ }^{10}$

Today the euro is the second most important international currency. Around 340 million European citizens use euro banknotes and coins in the 19 member states of the euro area. Some 60 countries of the world use the euro or peg their own currencies to it. It is a widely accepted currency for international payments, and a substantial portion of the FX reserves of foreign banks, and debt traded in international markets, is also in euro.

In his September 2018 State of the Union speech, President Juncker emphasised the strategic importance of the euro and the need for it to fulfil the role of a common currency in the international arena, saying that the global role of the euro should be enhanced by decisions aimed at strengthening European Economic and Monetary Union, and by the completion of the Banking Union, so that the common currency can reflect the political, economic and financial weight of the euro area in the global space.

\subsection{Digital challenges for the financial system of the European Union}

In the decade that followed the global financial crisis of 2008, during the last two EU cycles, the fourth industrial revolution got under way in the form of an era of digital advancement and digital transformation that also affected the financial sector. These changes were so rapid and far-reaching that the EU had to respond. The European Commission declared that the new digital technology would be a key element of the EU's future competitive advantage.

9 Sven Giegold (2017): Reform of the Eurozone: Commission supports Macron instead of Merkel (6 December).

10 EC (2018): Commission presents ways to further strengthen the euro's global role. Brussels, 5 December. 
There is no generally accepted definition of the term FinTech (financial technology) in economic literature. The Basel Committee on Banking Supervision (BCBS) uses the working definition of FinTech applied by the Financial Stability Board (FSB), according to which it means "technologically enabled financial innovation that could result in new business models, applications, processes, or products with an associated material effect on financial markets and institutions and the provision of financial services". The BCBS judges that this broad definition can be used pragmatically given the rapid pace of FinTech development. ${ }^{11}$

This permissive and broad definition naturally has serious implications. Because the definition does not clearly identify the content and scope of FinTech services, it may be difficult to establish statutory frameworks that define the boundaries of supervisory audits, and to ensure a level playing field in the competition between incumbent banks and FinTech companies.

In May 2015, the European Union started to elaborate an overarching plan referred to as the Digital Single Market Strategy, which was completed in 2017. Its main elements were the following: improving access to digital goods, services and content; establishing appropriate legal frameworks for digital networks and services; and leveraging the economic advantages of the data-based economy. To further the strategic goal of a more competitive, innovative financial market, in March 2018 the European Commission published a FinTech Action Plan, which concentrated on the leveraging of opportunities inherent in technology-enabled innovations in the field of financial services (FinTech).

"Europe should become a global hub for FinTech, with EU businesses and investors able to make most of the advantages offered by the Single Market in this fast-moving sector. As a first major deliverable, the Commission is also putting forward new rules that will help crowdfunding platforms to grow across the EU's single market."

The Action Plan set out to enable the financial sector to make use of the rapid advances in new technologies, such as blockchain, artificial intelligence and cloud services. The authorities and decision-makers of the European Union made an effort to keep pace with the rapid digital changes affecting the financial sector. This is clearly shown by the fact that on the day following publication of the EU's FinTech Action Plan, in March 2018, the European Banking Authority (EBA) issued its FinTech working plan entitled Designing a Regulatory and Supervisory Roadmap for FinTech.

11 KeRÉNYi ÁdÁm - MÜller János (2019): Szép új digitális világ? - A pénzügyi technológia és az információ hatalma [Brave New Digital World? The Power of Financial Technology and Information]. Hitelintézeti Szemle, 18 (1), March. 
The EBA's working plan is an important summation of the necessary and planned regulation of the services provided by conventional banks and FinTech startups. "Most of the current regulatory approaches sit in between these two extremes [of 'let things happen' and 'regulate and restrict']. They are generally based on three components: monitoring of innovation, assessment of risks vis-a-vis the public interest (micro-prudential, financial stability, consumer protection and market integrity), and selective application of the existing rulebook.

In general, this pragmatic approach revolves around a tiered regulatory structure, with differentiated regulatory requirements according to the risks for the firms, their customers, the financial sector and the economy at large. In principle, the objective is to deliver 'same risk, same rules' outcomes".

The digital processes affecting the financial sector have accelerated, and the Financial Stability Board and the European Central Bank have warned of the risks that are currently dismantling and endangering the structure of the financial market. A description of these processes falls outside the scope of this article, but we can draw attention to three of the consequences. Firstly, there is an intention to support FinTech startups, often with the objective of allowing central banks or supervisory authorities to gain a better understanding of the need for specific areas of regulation. Secondly, the rapid changes and cross-border services have given rise to a duality: The ECB and other supervisory bodies emphasise the need for international cooperation and joint action, the principles of 'same risk, same rules', but in the absence of any progress in this area they have declared that the regulation of FinTech must stay under national control. Thirdly, the need for selfregulation and ethical guidelines has begun to be emphasised, and the norms relating to this are starting to be developed.

In April 2019 the European Commission published its ethics guidelines for the building of trust in artificial intelligence. "The ethical dimension of AI is not a luxury label or accessory. Only if there is trust can our society make full use of these technologies. Ethical AI is a win-win proposition for everyone, which could turn into a competitive advantage for Europe: We could lead the way in people-centred AI that people can trust", declared the commissioner for the Digital Single Market. Seven basic criteria were defined for achieving trustworthy AI. To highlight just a few of these: 1 . Trustworthy AI should comply with all applicable laws and regulations. 2. Human agency and oversight: AI systems should facilitate a just society and human agency through the support of fundamental rights, and they must not restrict or hamper human autonomy. 3. Privacy and data protection: 
citizens must exercise full control over their own data, while data relating to them may not be used for harmful or damaging discrimination against them. ${ }^{12}$

With regard to the EU's financial architecture and digital challenges, we should mention a regulatory development that impacted the banking sector as a whole. As we have seen, the emergence of FinTech startup companies was met with support and consumer confidence; the banks and regulators regarded their market role as marginal. However, in the second half of the past decade, the spread of FinTech was revolutionary in its speed, and incumbent banks have indicated that the regulations do not ensure a level playing field, and the amendment of the PSD2 Payment Services Directive will result in a substantial loss of data and market for them if they do not immediately launch their own, highly costly digital developments. PSD2 permits third party providers (TPPs) to access the banks' current account management systems, and the data stored in them, via an API. This was a milestone in the relationship between conventional banks and FinTech-type service providers.

\subsection{Developments at the end of the cycle, prior to the European Parliament elections}

Just before the 2019 EP elections and the end of the current cycle, the European Commission assessed the European financial supervisory system and specified the establishment of a stronger and more integrated European financial supervisory architecture as a prerequisite for moving forward..$^{13}$

For the Commission, the publication of this document enabled the European Parliament and the member states to agree in March on the important elements of European money-market supervisory reforms, under which supervision in the European Union will be improved through a strengthening of the role and powers of the European Supervisory Authorities (ESAs). To ensure a well-functioning and viable Capital Markets Union (CMU), the EU needs to ensure that the supervisory authority can keep pace with the deepening integration. Besides this, the most recent money laundering incidents at EU banks have heightened the need for strengthening the anti-money laundering supervisory system.

Let us now take a closer look at the scope of this new authority. The European System of Financial Supervision (ESFS) was created in November 2010 after the

12 EC (2019): Artificial intelligence: Commission takes forward its work on ethics guidelines. Brussels, 8 April.

13 EC (2019): Capital Markets Union: Creating a stronger and more integrated European financial supervisory architecture, including on anti-money laundering. Brussels, 1 April. 
financial crisis, based on the recommendations of the expert group led by Jacques de Larosière. This system was set up to strengthen financial supervision and confidence in the EU's new financial system. The ESFS has two pillars: the three European supervisory authorities overseeing the individual sectors and institutions (the micro-prudential pillar), and the European Systemic Risk Board (ESRB), which supervises the financial system and coordinates the EU's financial stability policy (the macro-prudential pillar).

The three European Supervisory Authorities (ESAs) are the European Banking Authority (EBA), the European Insurance and Occupational Pensions Authority (EIOPA) and the European Securities and Markets Authority (ESMA). These contribute to the drafting of common rules relating to the EU's financial markets, including efforts to combat money laundering.

The European Supervisory Authorities are tasked with establishing better operating conditions for the single market for financial services, ensuring the integrity, transparency, efficiency and orderly functioning of the financial markets, preventing regulatory arbitrage, and making efforts to combat money laundering more effective.

The above-mentioned agreement emphasised that completion of the Banking Union and Capital Markets Union must continue. Accordingly, the European Banking Authority received the authority to take effective action against money laundering and terrorism financing within the EU's financial system, and to incorporate these requirements into the supervisory practices of all authorities concerned.

As a part of Capital Markets Union, the Commission elaborated a comprehensive strategy in order to facilitate the establishment of an integrated market for digital financial services.

The first step in supporting FinTech processes was for the European Supervisory Authorities to consider all the questions relating to technological innovation. This necessitates a strengthening of the culture of joint EU supervision between the competent authorities with regard to technological innovation. The European Supervisory Authorities were entrusted with coordinating national supervisory authorities' deployment at national level of technological innovation tools, such as innovation hubs or regulatory sandboxes.

The development of the past two cycles, as described above, and the development of the structure of the European financial system, and its main building blocks, are shown in the diagram below. 
Table 1

The structure of the European financial system and its main building blocks

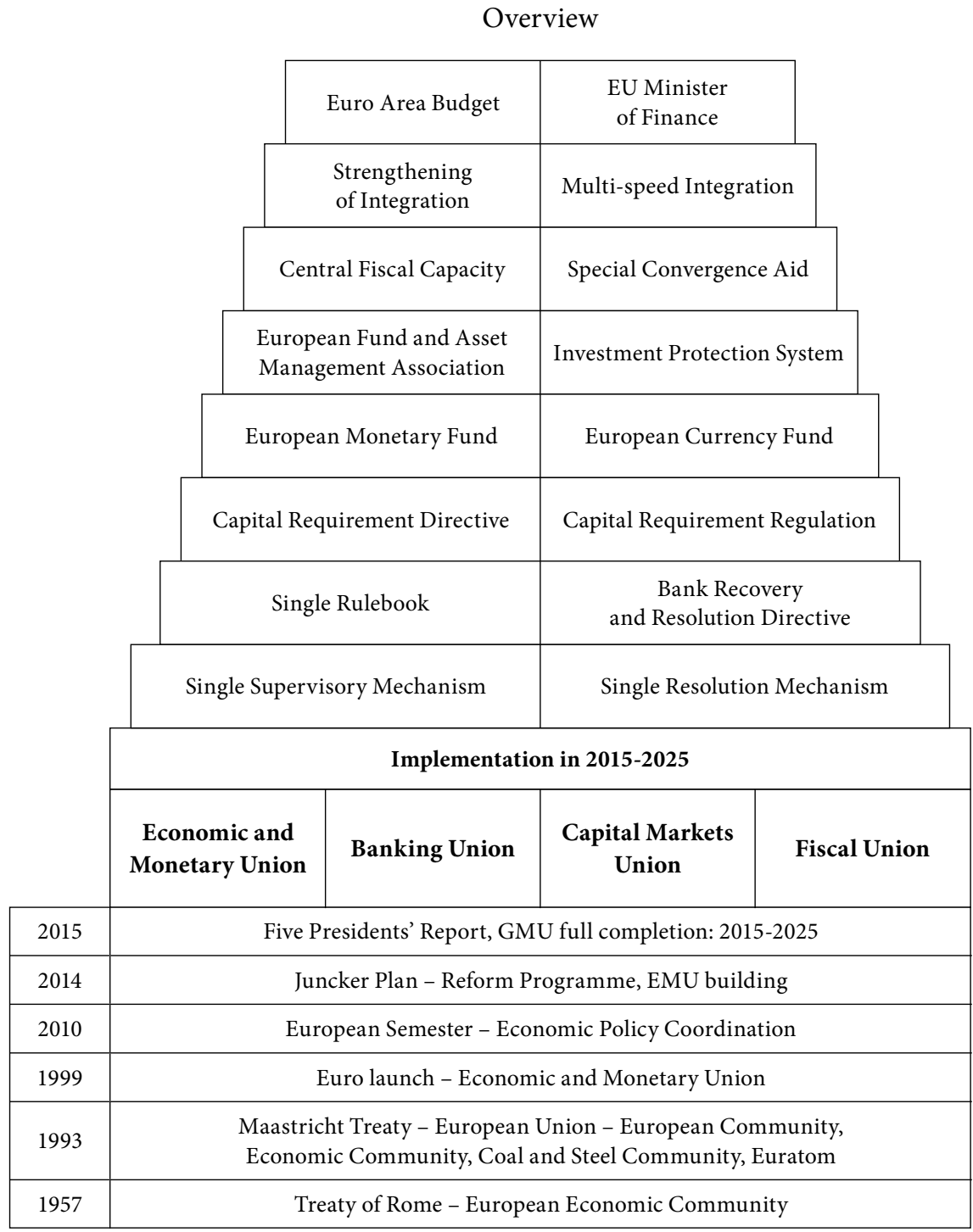




\section{FUTURE VISION OF THE STRUCTURE OF THE EUROPEAN FINANCIAL SYSTEM}

The financial system of the European Union has arrived at a crossroads, a time to take stock of the plans for its future shape. The road travelled so far has been evaluated by the European Parliament, the European Commission and the European Central Bank. In order to give an overview of the most important questions, this section is based on the findings of the European Parliament's Committee on Economic and Monetary Affairs. ${ }^{14}$

Questions regarding the foundations of the EU's financial structure: How should European Economic and Monetary Union continue to develop, what kind of reforms are needed for its better, more effective operation? How can it become more resistant to possible future shocks?

A question that needs to be answered first is whether a closer, deeper fiscal and political union is needed. Following the outbreak of the 2008 financial crisis, numerous analyses pointed out that the structure of the Monetary Union was incomplete. The cited analysis by the EU Parliament concluded that while deeper fiscal and political integration is not a prerequisite for the EMU's survival, it is certainly essential for moving forward, and this underlines the importance of strengthening the Single European Market and completing the Banking Union and Capital Markets Union. The level of development of the EMU, and past experience, show that deeper political integration in the context of the EU and EMU contribute to the sustainability of the European Economic Area.

How can fiscal and political union be strengthened? To determine this, we need to answer the question of what advantages may result from such a centralisation of funds and competencies. It is a fundamental requirement that any further centralisation of competencies already accessible by the EU/EMU should promote the achievement of common political goals; the arising additional costs must be compensated for, improving the efficiency of the integration. The deepening of integration in these areas, and the corresponding expansion of the EU's mandate, should be accompanied by growth in the EU's budget. This development, on the other hand, gives greater scope for the application of an EU-level anticyclical policy; it would be possible to make use of federal buffers to cushion asymmetrical shocks.

14 EP (2019): The Economic and Monetary Union: Past, Present and Future. ECON Committee, European Parliament, January. 
In summary, we can conclude that the majority of the EU's opinion leaders and expert advisors consider the completion of fiscal and political integration to be necessary in order to finish construction of the EMU.

As regards the future of the European Monetary Union, a cardinal question in the forthcoming cycle will be the expansion of the EMU, which stopped after Lithuania joined in 2015. Besides the 19 member states, if we disregard the special cases of the United Kingdom, Denmark and Sweden, six countries remain outside the mechanism. Of these, Bulgaria, Romania and Croatia have announced their decision to join, but the Czech Republic, Hungary and Poland do not believe the time is right to do so. The European Commission's position regarding this issue, which has become steadily stronger since the State of the Union document was published in 2017, is that it is desirable for the euro to be the EU's only currency. In 2018 the Commission set aside a Dedicated Convergence Facility for the period after 2020, accessible to the countries that intend to join. This aid is available under the approved Structural Reform Support Programme. In the EU, the generally held and increasingly firm political standpoint is that for the countries that remain on the outside a multi-speed Europe will become more complicated, the decision-making system will not become sufficiently robust, and those on the inside are becoming increasingly vocal in their criticism of the convergence aid provided to the outsiders.

With regard to the EU's financial architecture, its metaphorical residents and suppliers of raw materials, namely the banks, also have a vision for the 2019-2024 cycle. This vision has been developed by the European Banking Federation, which represents the banking associations of 31 countries (EU member states and associated countries). ${ }^{15}$ The following is a summary of their most important conclusions:

- There should be an integrated, unified, strong financial sector, which finances sustainable economic growth. To achieve this, the European Banking Union and Capital Markets Union should work at local, regional and pan-European levels of access, in a fully integrated environment.

- Banks should focus on stable bank-customer relationships rather than on individual transactions.

- The conditions for competition in the bank sector should be fair and ensure a level playing field.

15 EBF (2019): Boosting Europe: EBF recommendations for the EU 2019-2024 legislative policy cycle and beyond. Manifesto, May.

EBF (2018): Financing the Europe of Tomorrow. A vision for policy makers, banks and markets in a changing world. 
- Capital Market Union must be completed. Banks should continue to be key actors in the capital markets. Accordingly, there should be a larger capital market but not a smaller banking market.

- To ensure the safe and profitable operation of the Money Market Union and the banks, the regulation need to be reviewed and refined, removing any possible hindrances created by the regulation. The current prudential regulations must be reviewed - where necessary - with respect to the capital and liquidity requirements, insofar as they restrict the banks' lending capability.

- The Digital Single Market needs to be created, and the banks must be treated as essential partners in its implementation.

- Investor protection and financial literacy must be strengthened.

These elements of the vision of the European Banking Community must not be treated as mere slogans. In the interest of attaining these goals, the banking sector will support the EU's decision makers in their aspirations that are consistent with their vision of the future, or it will oppose developments that are negative for the sector. In short, the banks will play an active part in shaping the financial architecture of the European Union.

\section{SUMMARY AND CONCLUSIONS}

As the European Union arrives at an important crossroads, numerous analyses and discussion papers have been published recently on its present situation and on its future. These covered the whole spectrum of opinion, generally assessing the situation in political terms, from predictions of a bright future to those of the Union's disintegration. Without a doubt, there has been no shortage of difficult and unexpected events in the past decade. We have lived through a global financial crisis, a recession and tax crisis; later geopolitical tensions emerged and escalated, a trade war on a scale unseen for decades blew up and intensified, and finally we have also had the several years of uncertainty surrounding Brexit. With all this in the background it is understandable, if not acceptable, that numerous analyses and predictions are driven by the emotional/political impacts of the negative developments rather than being based on facts and expertise. In this regard, the sensitive reaction of the financial sector and money markets to these processes deserves a special mention.

Bearing all this in mind, on the threshold of a new cycle, we set out to review the development of the architecture of the European Union's financial structure in the past decade, which is also what will define the future conditions for the banking sector's continued operation. Likening this structure to a building we have 
also described, in the necessary extent, the foundations on which it was possible to construct the metaphorical walls and interior spaces.

We referenced three iconic anniversaries: the $60^{\text {th }}$ birthday of the Treaty of Rome, which made it possible to create the European Economic Community, the $25^{\text {th }}$ anniversary of the Maastricht Treaty on the European Union, and the $20^{\text {th }}$ year since the launch of the euro and creation of the euro area. These red-letter days show that the foundations are solid, and that dismantling them would have unforeseeable consequences. So, there were solid foundations to build on. These foundations brought over seven decades of peace, affluence and development for Europe. It makes sense, therefore, to examine the development and vision of the EU in a historical perspective, and accordingly we have analysed - more or less in chronological order - the developments of the last two cycles. In the past decade, the operating mechanism of the European Union and the building of its institutions has been influenced, helped and sometimes hindered by numerous factors. Going back to the roots, we referred to the documents relating the EEC itself, the European Union and the foundation of the euro area, because these are what defined the conditions for operation and fulfilment of the commonly accepted future objectives. The "running" of all this required political decisions, and in certain cases political intent and will. These were sometimes motivated, and at others restrained, by events that took place during the two cycles. The fundamental changes that followed the formation of the EEC, and later the European Union, were precipitated by the introduction of the euro twenty years ago, and by the establishment of Economic and Monetary Union. From this point on, the EU split into two parts: the euro area, which now has nineteen members, and the group of outsiders or prospective joiners. Once the euro area had strengthened and shown itself to be viable, the global financial crisis of 2008 broke out.

These antecedents had a major impact on the development of the EU's financial institutions and regulatory system. It became clear that the EU was not equipped to manage financial shocks on this scale. One the one hand there was a swing towards overregulation of the financial and banking system, a transformation and amendment of the system of institutions applying the rules. On the other, the EU had proven capable of overcoming the crisis, and this forced political recognition of the need to strengthen the Union, and the euro area in particular. The European Union came in for much criticism - some of it justified - regarding the crisis management. For a long time, it appeared that a double periphery was emerging. The first group comprised Greece, Italy, Spain, Portugal and Ireland, while the second consisted of most of the countries outside the euro area. The serious impacts of the crisis had been successfully dealt with by the middle of the past decade, and the EU's economy started to show growth. Given all the criticisms raised in connection with the Greek crisis it is worth noting that it was not 
the country's EU membership that caused it to be so hard-hit by the crisis, and we can only imagine what would have happened if Greece had not been a member of the European Union at the time.

In the cycle that began in 2014, development of the EU's financial system got under way at several interacting levels. Firstly, the plans marking out the desirable directions and priorities for development (Juncker Plan, Five Presidents' Report, European Semester) were drawn up and approved. Common features of these were the strengthening of integration, competitive and sustainable economic growth and the creation of a robust financial system capable of withstanding external shocks. It was deemed necessary to construct four pillars on the existing foundation: Economic and Monetary Union, Capital Market Union, Fiscal Union and Political Union.

It was within this framework that the development of the financial regulatory system and the institutions under the above-mentioned four pillars took place.

With regard to the regulatory system, two different processes got under way. Firstly, a post-crisis review of the crisis management rules was performed in the context of the Better Rules, Better Results programme. Secondly, efforts to put in place the elements necessary for Economic and Monetary Union were accelerated.

The operation of the European System of Financial Supervision was supported by two institutions, the European Systemic Risk Board and the three European Supervisory Authorities, the European Banking Authority, the European Insurance and Occupational Pensions Authority and the European Securities and Markets Authority. The Single Supervisory Mechanism, the Single Resolution Mechanism and the Single Resolution Fund were established and went into operation, and development of the Single Deposit Insurance Scheme also got under way. The European Stability Mechanism was supplemented with the Common Backstop and later the European Monetary Fund.

During the period behind digital advancement caught up with the EU which, sensing the importance of this, elaborated the concept of the Digital Single Market in 2015. The process rapidly, and sometimes aggressively spilled over into the traditional banking market. The EU's FinTech Action Plan was drawn up, but FinTech regulation remains patchy to this day, and is not capable of guaranteeing the principle of 'Same Risk, Same Rules'.

Before the 2019 European Parliament Elections, the European Commission evaluated the situation of the financial system, mapping out the tasks ahead for the prospective new leaders of the EU. It concluded that the Monetary Union has advanced considerably, but stronger and more consistent financial integration is needed, and to this end an agreement was made on the reform of the financial su- 
pervision system and a strengthening of the powers of the money-market supervisory bodies. Achieving the full completion of the Banking Union and Capital Markets Union will be of key importance in the next cycle.

And this brings us to the future vision of the EU's financial and banking system. In the years immediately following the crisis, and in the last two cycles, the development of the EU's financial system has come a long way. The main elements of the way forward are clear. In order to finish constructing the Monetary, Capital Markets and Banking Union, major political decisions are needed. The areas in which progress has not been made are Fiscal Union, a more integrated common budget, closer coordination of fiscal and economic policy, the creation of the post of EU minister of finance, and a stronger convergence process subjected to stricter conditions. A similarly cardinal question relates to the form in which a two-speed Europe can continue, this being essential to the financial architecture, and to how and at what cost the euro area can be expanded and made complete, because without this Monetary Union cannot be completed either. We have a complex period ahead of us in many respects. Some of the towering problems, such as the geopolitical tensions, the trade war, the failed transatlantic agreement with the USA, or even any of the possible outcomes of Brexit, pose major challenges; but at the same time they will certainly help political efforts aimed at strengthening the core countries of Europe.

\section{REFERENCES}

BASTASIN, C. (2015): TheEuro and the End of 2oth Century Politics. LUISS School of European Political Economy, October 2015.

BCBS (2017): Implications of fintech developments for banks and bank supervisors. BIS, 31 August, https://www.bis.org/bcbs/publ/d415.htm.

CAPpiello, S. (2015): The interplay between the EBA and the Banking Union. Robert Schuman Centre for Advanced Studies, Working Paper, EUI RSCAS, 2015/77, 23 October.

Darvas, Zs. - LeAndro, A. (2015): The limitations of policy coordination in the euro area under the European Semester. Bruegel, November.

EBF (2016): Transatlantic Financial Regulatory Coherence Coalition: Financial Regulation in the TTIP. International Coalition for Transatlantic Cooperation in Financial Regulation. https:// www.ebf.eu/regulation-supervision/transatlantic-financial-regulatory-coherence-coalitionfinancial-regulation-in-the-ttip/, 7 Juin.

EBF (2018): Financing the Europe of Tomorrow. A vision for policy makers, banks and markets in a changing world. https://www.ebf.eu/financing-growth/vision-paper-financing-the-europe-oftomorrow/, 27 September.

EBF (2019): Boosting Europe: EBF recommendations for the EU 2019-2024 legislative policy cycle and beyond. Manifesto, https://www.ebf.eu/eu-agenda-2019-2024/boosting-europe-ebf-recommendations-for-the-eu-2019-2024-legislative-cycle-and-beyond-manifesto/, May. 
EC (2015a): The Five President's Report: Completing Europe's Economic and Monetary Union. 22 June.

EC (2015b): Transatlantic Financial Regulatory Coherence Coalition: Financial Regulation in the TTIP. July.

EC (2015c): State of the Union 2015: https://ec.europa.eu/commission/publications/state-union2015-european-commission-president-jean-claude-juncker_en, 9 September.

EC (2015d): Capital Markets Union: Vital for Growth - Jonathan Hill; Eurofi Financial Forum, 10 September.EC (2015): Action plan on building a capital markets union European Commisssion. https://ec.europa.eu/info/publications/action-plan-building-capital-markets-union_en, 3o September.

EC (2016a): Investment Plan for Europe: European Fund for Strategic Investments to be extended following successful first year; .European Commission, 1 Juin.

EC (2016b): Joint letter of Presidents Donald Tusk and. Jean-Claude Juncker on the upcoming G2O summit. Press release, https://www.consilium.europa.eu/hu/press/press-releases/2019/o6/26/ joint-letter-of-presidents-donald-tusk-and-jean-claude-juncker-on-the-upcoming-g2o-summit/, 26 Juin.

EC (2018a): New measures to boost key competences and digital skills, as well as the European dimension of education. Press release, https://ec.europa.eu/digital-single-market/en/news/newmeasures-boost-key-competences-and-digital-skills-well-european-dimension-education, 17 January.

EC (2018b): Speech by Commissioner Gabriel on building the European digital economy and society at the DLD conference. München, 22 January, https://ec.europa.eu/commission/presscorner/detail/en/SPEECH_18_39o.

EC (2016c): Investment Plan for Europe: European Fund for Strategic Investments to be extended following successful first year. 1 Juin.

EC (2018d): ,Investment Plan results' - Investment Plan for Europe, July.

EC (2018e): Commission presents ways to further strengthen the euro's global role. Brussels, 5 December.

EC (2019a): Capital Markets Union: Creating a stronger and more integrated European financial supervisory architecture, including on anti-money laundering. European Commission. Brussels, 1 April.

EC (2019b): Artificial intelligence: Commission takes forward its work on ethics guidelines). Brussels, 8 April.

EC (s. a.): What is the Investment Plan for Europe?, https://ec.europa.eu/info/investment-plan-europe/what-investment-plan-europe_en.https://ec.europa.eu > investment-plan-europe-junckerplan.

EP (2015): Opinion of European Think Tanks on the EMU. 18 December.

EP (2019a): The Economic and Monetary Union: Past, Present and Future. ECON Committee, European Parliament, January.

EP (2019b): Factsheet: The Juncker Plan's impact on jobs and growth, October.

EU-EP (2017): Parliament sets out its vision for the future of Europe]. Plenary Session Press release - Future of Europe/European integration/Institutions, 16-02-2017.

Giegold, S. (2017): Reform of the Eurozone: Commission supports Macron instead of Merkel. EP Diegrünen/EFA, 6 December.

GNATH, K. (2015): Why the euro area needs new convergence goals. Bertelsmann Stiftung, 4 December.

Gros, D. - Alcidi, C. (2015): Economic policy coordination in the euro area under the European Semester. Centre for European Policy Studies, No. 123, December. 
HaAs, J. (ed., 2015): A fiscal union for Europe: Building block and not a magic bullet. Jacques Delors Institute - Berlin, Bertelsmann Stiftung, October 2015.

IIEA (2015): Comments on the five presidents' report, 'Completing Europe's Economic and Monetary Union'. iiea.com, 17 November.

IMF (2015): Building a Better Union: Intensivizing Structural Reforms in the Euro Area. IMF Working Paper, September.

Kerényi ÁdÁm - Müller János (2019): Szép új digitális világ? - A pénzügyi technológia és az információ hatalma. Hitelintézeti Szemle, 18 (1), március.

LARCH, M. - EC (2014): European Commission: The Stability and Growth Pact (SGP). In: DurLauf, S. N. -Blume, L. E. (eds, 2014): The New Palgrave Dictionary of Economics, Chapter: The Stability and Growth Pact of the European Union, Palgrave Macmillan.

LOURI, H.(2017): A fourth pillar for Europe's banking union? The case for a pan-European asset management company in the Eurozone. European Politics and Policy, London School of Economics, 6 December.

QUED (2018): Conference on the Future of European Financial Infrastructure. 11 October.

Tusk, D. (2017): Speech by President Donald Tusk at the ceremony of the 6oth anniversary of the Treaties of Rome. https://www.consilium.europa.eu/en/press/press-releases/2017/03/25/tuskceremony-rome-speech/, 25 March.

Ungvári Tamás (2015): Csalódások kora [Age of Disappointments]. Budapest, Scolar Kiadó, 519. o.

ZuLEEG, F. (2015): Can the eurozone's economic governance combine political accountability, legitimacy and effectiveness? European Policy Centre, 1 September.

ZuLEEG, F. (2015): Unfinished Business: the governance of the Economic and Monetary Union). European Policy Center, 18 September. 